\title{
The prevalence and associated factors of cigarette smoking and its association with opium use among outpatients in Afghanistan: a cross-sectional study in Andkhoy city
}

\begin{abstract}
Mohammad Shoaib Hamrah, Mohammad Hassan Hamrah ${ }^{1,2}$, Mohammad Hussain Hamrah ${ }^{1,3}$, Ahmad Edris Hamrah' ${ }^{1}$, Toba Dahi4, Bagher Pahlavanzade , Abdurrahman Charkazi ${ }^{6}$, Mohammad Hashem Hamrah

Center for Rural Health, School of Health Sciences, University of Tasmania, Tasmania, Australia, ${ }^{1}$ Dr. Mohammad Hashem Hamah's Curative Clinic, Andkhoy, Faryab, Afghanistan, ${ }^{2}$ Faculty of Stomatology, Kunduz University, Kunduz, Afghanistan, ${ }^{3}$ Faculty of Medicine, Arya University, Mazar-i-Sharif, Afghanistan, ${ }^{4}$ Faculty of Dentistry, Abantlzzet Baysal University, Bolu, Turkey, ${ }^{5}$ Department of Biostatistics, Faculty of Paramedical Sciences, Shahid Beheshti University of Medical Sciences, Tehran, Iran, ${ }^{6}$ Environmental Health Research Center, School of Health, Golestan University of Medical Sciences, Gorgan, Iran
\end{abstract}

\begin{tabular}{|c|}
\hline Access this article online \\
\hline Website: www.avicennajmed.com \\
\hline DOI: 10.4103/ajm.AJM_40_19 \\
\hline Quick Response Code: \\
\hline
\end{tabular}

\begin{abstract}
Purpose: The objectives of this study were to estimate the prevalence and associated factors of cigarette smoking and the association between cigarette smoking and opium use among patients visiting an outpatient clinic in Afghanistan. Methods: A cross-sectional study was conducted on consecutive patients aged 18 years and older from January 2018 to April 2018. Data on patients' sociodemographic characteristics and clinical variables were collected using an interview-based survey. Results: Six hundred and twenty-two patients (391males vs. 231 females) were interviewed for this study. The overall prevalence of current smoking was $50.2 \%$ (95\% confidence interval [Cl]: 46.2-54.2). Males were (odds ratio $[\mathrm{OR}]=9.5 ; 95 \% \mathrm{Cl}: 5.3-17.1)$ more likely to smoke cigarettes than females. The odds of current cigarette smoking increased with having a family member smoker or a friend smoker $(\mathrm{OR}=3.3 ; 95 \% \mathrm{Cl}: 2.0-5.3)$. Cigarette smoking was significantly associated with the level of education (illiterate $\mathrm{OR}=8.9 ; 95 \% \mathrm{Cl}: 4.0-19.8)$, primary/private education $(\mathrm{OR}=7.8 ; 95 \%$ $\mathrm{Cl}$ :3.9-15.6), and secondary education ( $\mathrm{OR}=4.4 ; 95 \% \mathrm{Cl}: 2.3-8.4)$, with high school or higher education as the reference group. Rural residents were 3.7 times (95\% Cl: $2.3-6.2$ ) more likely to smoke cigarette than urban residents. Opium users were 23.0 times $(95 \%$ $\mathrm{Cl}$ : 12.5-42.3) more likely to smoke cigarettes than non-opium users. Conclusions: The prevalence of cigarette smoking among patients visiting an outpatient clinic in Afghanistan was high, and there was an association between cigarette smoking and male gender, a family history of smoking or a friend history of smoking, level of education, rural residency, and opium consumption.
\end{abstract}

Key words: Andkhoy, associated factors, opium use, smoking

\section{INTRODUCTION}

Tobacco use is one of the main preventable risk factors for noncommunicable diseases including cancers, cardiovascular disease, diabetes mellitus, and chronic

Address for correspondence: Dr. Mohammad Shoaib Hamrah, Centre for Rural Health, School of Health Sciences, University of Tasmania, Locked Bag 1322, Launceston TAS 7250 Australia. E-mail: mshoaibhamrah@gmail.com
This is an open access journal, and articles are distributed under the terms of the Creative Commons Attribution-NonCommercial-ShareAlike 4.0 License, which allows others to remix, tweak, and build upon the work non-commercially, as long as appropriate credit is given and the new creations are licensed under the identical terms.

For reprints contact: reprints@ @medknow.com

Cite this article as: Hamrah MS, Hamrah MH, Hamrah MH, Hamrah AE, Dahi $\mathrm{T}$, Pahlavanzade $\mathrm{B}$, et al. The prevalence and associated factors of cigarette smoking and its association with opium use among outpatients in Afghanistan: A cross-sectional study in Andkhoy city. Avicenna J Med 2019;9;129-33. 
lung disease. ${ }^{[1]}$ Tobacco use causes approximately 6 million deaths annually. If these trends continue, this number is projected to increase to 8 million per year by $2030 .^{[2]}$ Of the 1.3 billion smokers worldwide, $80 \%$ of them live in low- and middle-income countries (LMICs). Most LMICs have less access for the adequate care of patients with a tobacco-related illness. ${ }^{[3]}$

The high smoking rates reported among illicit drug users were from population-based studies and among patients attending substance abuse treatment clinics and facilities. ${ }^{[4]}$ The prevalence of concurrent smoking and substance use was between $35 \%$ and $44 \%$ in the general population, whereas this figure for patients attending the substance abuse treatment clinics and facilities was $80 \% .{ }^{[5]}$

Afghanistan has been the world's biggest producer of opium. ${ }^{[6]}$ There is a paucity of studies regarding prevalence of cigarette smoking and its associated factors, and the association between cigarette smoking and opium use among a population of outpatients in Afghanistan. Therefore, the primary aim of this study was to estimate the prevalence and identify independently associated factors with cigarette smoking among adult patients visiting an outpatient clinic. Secondary objective was to determine the association between cigarette smoking and opium use among patients visiting an outpatient clinic in Andkhoy, Afghanistan.

\section{SUBJECTS AND METHODS}

From January 2018 to April 2018, we performed a crosssectional study among 622 consecutive patients aged 18 years and older visiting an outpatient clinic in Andkhoy, Afghanistan. The exclusion criteria were the patients with physical and neurocognitive disorders and $\geq 80$ years of age.

Well-trained doctors collected the required information using the Persian version of World Health Organization stepwise approach to noncommunicable diseases risk factors surveillance, and the questionnaire has been validated. ${ }^{[7]}$ The questionnaire was modified into the Dari language. Persian and Dari are mutually intelligible varieties of the same language. Language experts confirmed the equivalence of the concept in the questionnaire. Moreover, the cultural validation has been made to check appropriateness of wording and to exclude the potential misinterpretation due to different ways of thinking. Data were collected on patients' sociodemographic characteristics, behavior risks, and physical and laboratory measurements. Questions were asked through face-to-face interviews. The following variables were investigated:
- Sociodemographic characteristics: Age, sex, education level, marital status, occupation, and place of residence

- Behavioral: Cigarette smoking and opium use

- Clinical characteristics: body mass index (BMI) and measured blood pressure

Fasting blood sugar, total cholesterol, and triglyceride were also measured. The variables are defined in elsewhere. ${ }^{[8]}$

Smoking: Patients were categorized into three groups: current smokers, past smokers, and nonsmokers. Current smokers were defined as patients who have smoked at least 100 cigarettes in their lifetime and had smoked in the last 30 days. Past smokers were defined as patients who had smoked at least 100 cigarettes in their lifetime but had not smoked in the last 30 days. Nonsmokers were defined as patients who had never smoked cigarettes in their lifetime. Both past smokers and those who had never smoked were constituted in the nonsmokers category. ${ }^{[9]}$

Opium consumption: Opium users reported using any types of opium at least once per week for last 6-month period. ${ }^{[10]}$ All the patients were interviewed as the diagnostic criteria specified in the Diagnostic and Statistical Manual of Mental Disorders IV criteria for opium dependency. ${ }^{[1]}$

BMI was calculated as weight in kilograms divided by height in meters squared. Overweight was a BMI $\geq 25 \mathrm{~kg} /$ $\mathrm{m}^{2}$, and obesity was a BMI $\geq 30 \mathrm{~kg} / \mathrm{m}^{2} \cdot{ }^{[12]}$ Hypertension: Hypertension was defined as systolic blood pressure/ diastolic blood pressure of $140 \mathrm{~mm} \mathrm{Hg}$ or diastolic blood pressure of $\geq 90 \mathrm{~mm} \mathrm{Hg}$ or higher, at separate occasions, and those already on antihypertensive medications at the time of admission. ${ }^{[13]}$ Questions were illustrated if there was need for more explanation about the concept of a question. Informed consent was obtained from the participants. The study was approved by the Faryab Public Health Directorate.

\section{Statistic al analysis}

All of the data were analyzed using IBM SPSS version 24.0 (SPSS; IBM Corp, Armonk, NY). The independent samples t-test was used to compare the means of quantitative variables across smokers and non-smokers. Results for quantitative data are represented as mean and standard division. The chi-square test was used to compare qualitative data in the two groups. Results for categorical data are represented in frequency and percentage. Multiple logistic regression analysis was used to identify factors associated with cigarette smoking and the association between cigarette smoking and opium use. The odds ratios (ORs) and 95\% confidence intervals (CIs) were calculated to determine 
association in the logistic regression analysis. The level of statistical significance was determined by $P<0.05$.

\section{RESULTS}

Table 1 indicates the sociodemographic and clinical characteristics of all patients. The mean age of the smokers and nonsmokers was $67.8 \pm 12.3$ years and $66.7 \pm 13.8$ years, respectively. The man-to-woman ratio among participants was 1.7. The overall prevalence of current smoking was 50.2\% (95\% CI: 46.2-54.2). The prevalence of current cigarette smoking among males was $76.0 \%$ (95\% CI: 71.0-80.6), and this was significantly higher than among females $21.2 \%$ (95\% CI: 16.8-26.1, $P<0.001$ ). The majority of smokers were illiterate $68.9 \%$ (95\% CI: 63.5-74.0). There was a high prevalence of smoking among married patients $84.3 \%$ (95\% CI: 79.8-88.1). Smoking prevalence was significantly higher among opium users $57.1 \%$ (95\% CI: 51.5-62.6) compared with nonuser groups $42.9 \%$ (95\% CI: 37.4-48.6) smoking was not equal among 4 occupation groups. The high smoking rates were observed among unemployed participants $67.3 \%$ (95\% CI: 61.8-72.5), among rural residents $49.4 \%$ (95\% CI: 43.7-55.0), among those who had a family member smoker or friend smoker 56.1\% (95\% CI: 50.4-61.7), and smokers mostly didn't have hypertension ( $44.6 \%$ versus $57.1 \%)$.

Table 2 represents the results of logistic regression analysis of smoking cigarettes among patients for sociodemographic characteristics, clinical variables, and opium use. Male participants were $(\mathrm{OR}=9.5$; 95\% CI: 5.3-17.1) more likely to smoke than female patients. Those patients who currently had a smoker family member or a smoker friend had 3.3 times (95\% CI: 2.0-5.3) greater odds to be a smoker. Those that had secondary education were about 4.4 times $(95 \%$ CI: 2.3-8.4) more likely, those that had primary/private education were 7.8 times (95\% CI: 3.9-15.6) more likely, and those that had no education were 8.9 times (95\% CI: 4.0-19.8) more likely to smoke cigarettes than those with high school or higher education. Rural residents were 3.7 times (95\% CI: 2.3-6.2) more likely to smoke cigarettes than urban residents. Opium users were 23.0 times (95\% CI: $12.5-42.3)$ more likely to smoke cigarettes than nonopium users.

\section{DISCUSSION}

This article examined the prevalence and associated factors of cigarette smoking and opium use among patients visiting an outpatient clinic in Afghanistan. Our findings show that the prevalence of cigarette smoking among patients visiting

\begin{tabular}{|c|c|c|c|}
\hline \multicolumn{4}{|c|}{$\begin{array}{l}\text { Table I: Association between sociodemographic and } \\
\text { health variables, and smoking among adult patients } \\
\text { visiting an outpatient clinic in Andkhoy, Afghanistan }\end{array}$} \\
\hline & Smokers & Nonsmokers & $P$ value \\
\hline & $(N=3 \mid 2)$ & $(N=310)$ & \\
\hline \multicolumn{3}{|l|}{ Age, $n(\%)$} & 0.424 \\
\hline$<39$ & 14 (4.5) & $22(7.1)$ & \\
\hline $40-60$ & $57(18.3)$ & $54(17.4)$ & \\
\hline$>60$ & $118(37.8)$ & $122(39.3)$ & \\
\hline \multicolumn{3}{|l|}{ Gender, $n(\%)$} & $<0.001$ \\
\hline Male & $244(78.2)$ & II 5 (37.I) & \\
\hline Female & $68(21.8)$ & $195(62.9)$ & \\
\hline \multicolumn{3}{|l|}{ Level of education, $n$ (\%) } & $<0.001$ \\
\hline Illiterate & $215(68.9)$ & $104(33.5)$ & \\
\hline Primary/private & 49 (I5.7) & $73(23.5)$ & \\
\hline \multicolumn{4}{|l|}{ education } \\
\hline Secondary & $28(8.9)$ & $83(26.8)$ & \\
\hline High school or more & $20(6.4)$ & $50(16.1)$ & \\
\hline \multicolumn{3}{|l|}{ Marital status, $n(\%)$} & 0.031 \\
\hline Single & $37(11.8)$ & $30(9.7)$ & \\
\hline Married & $263(84.3)$ & $254(81.9)$ & \\
\hline Others & $12(3.8)$ & $26(8.4)$ & \\
\hline \multicolumn{3}{|l|}{ Opium use, $n(\%)$} & $<0.001$ \\
\hline Yes & $178(57.0)$ & $54(17.4)$ & \\
\hline No & $134(42.9)$ & $256(82.6 \%)$ & \\
\hline \multicolumn{3}{|l|}{ Occupation, $n$ (\%) } & $<0.001$ \\
\hline Employed & $16(5.1)$ & $48(15.5)$ & \\
\hline Unemployed & $210(67.3)$ & $113(36.4)$ & \\
\hline House wife & $66(21.1)$ & $108(34.8)$ & \\
\hline Farmer & $17(5.4)$ & $27(8.7)$ & \\
\hline Others & $3(0.96)$ & $14(4.5)$ & \\
\hline \multicolumn{3}{|l|}{ Residence, $n(\%)$} & $<0.001$ \\
\hline Rural & I54 (49.3) & $110(35.5)$ & \\
\hline Urban & $158(50.6)$ & $200(64.5)$ & \\
\hline $\begin{array}{l}\text { History of family smoking, } \\
n(\%)\end{array}$ & $175(56.1)$ & III (35.8) & $<0.001$ \\
\hline \multicolumn{3}{|l|}{ Hypertension, $n(\%)$} & 0.002 \\
\hline Yes & $139(44.5)$ & $177(57.1)$ & \\
\hline No & $173(55.4)$ & $133(42.9)$ & \\
\hline $\begin{array}{l}\text { Body mass index, } \mathrm{kg} / \mathrm{m}^{2} \\
\text { mean } \pm \mathrm{SD}\end{array}$ & $23.6 \pm 2.9$ & $25.2 \pm 3.6$ & $<0.001$ \\
\hline $\begin{array}{l}\text { Fasting blood sugar (mg/dL) } \\
\mathrm{mm} \mathrm{Hg} \text {, mean } \pm \mathrm{SD}\end{array}$ & $106.3 \pm 34.4$ & $104.2 \pm 23.7$ & 0.516 \\
\hline $\begin{array}{l}\text { Total cholesterol }(\mathrm{mg} / \mathrm{dL}) \\
\mathrm{mm} \mathrm{Hg} \text {, mean } \pm \mathrm{SD}\end{array}$ & $|79.4 \pm 3| .8$ & $177.6 \pm 34.3$ & 0.349 \\
\hline $\begin{array}{l}\text { Triglyceride }(\mathrm{mg} / \mathrm{dL}) \mathrm{mm} \\
\mathrm{Hg}, \text { mean } \pm \mathrm{SD}\end{array}$ & $158.4 \pm 39.4$ & $160.1 \pm 37.2$ & 0.722 \\
\hline
\end{tabular}

an outpatient clinic in Afghanistan was high, and the study also revealed that factors associated with smoking were male gender, education level, rural residency, and opium consumption among adult patients who visited an outpatient clinic in Andkhoy, Afghanistan.

The prevalence of current cigarette smoking in this study was high (50.3\%). This rate is comparable with the cigarette smoking prevalence rate obtained from a study among patients of a tobacco cessation clinic of a tertiary care teaching hospital in Bangalore, India (49\%). ${ }^{[14]}$ However, the prevalence of smoking reported in this study was lower than those reported among those attending an anti-smoking 


\begin{tabular}{|c|c|c|c|c|c|}
\hline \multirow{2}{*}{$\begin{array}{l}\text { Variables } \\
\text { Gender }\end{array}$} & \multicolumn{2}{|c|}{ Number (\%) } & \multirow[t]{2}{*}{ OR } & \multirow[t]{2}{*}{$(95 \% \mathrm{Cl})$} & \multirow{2}{*}{$\begin{array}{l}P \text { value } \\
<0.001\end{array}$} \\
\hline & & & & & \\
\hline Female & 36 & $(1 \mathrm{I} .5)$ & I & & \\
\hline Male & 276 & (88.5) & 9.5 & $(5.3-17.1)$ & \\
\hline Family member smoking & & & & & $<0.001$ \\
\hline No & 137 & $(43.9)$ & 1.0 & & \\
\hline Yes & 175 & $(56.1)$ & 3.3 & $(2.0-5.3)$ & \\
\hline \multicolumn{6}{|l|}{ Education } \\
\hline High school or higher & 20 & $(6.4)$ & 1.0 & & \\
\hline Secondary & 40 & $(12.8)$ & 4.4 & $(2.3-8.4)$ & $<0.001$ \\
\hline Primary/private education & 18 & $(5.8)$ & 7.8 & $(3.9-15.6)$ & $<0.001$ \\
\hline Illiterate & 234 & $(75.0)$ & 8.9 & $(4.0-19.8)$ & $<0.001$ \\
\hline \multicolumn{6}{|l|}{ Occupation } \\
\hline Employed & 16 & $(5.1)$ & 1.0 & & \\
\hline House wife & 66 & $(21.1)$ & 0.5 & $(0.23-1.2)$ & 0.113 \\
\hline Farmer & 17 & $(5.4)$ & 1.4 & $(0.6-3.5)$ & 0.466 \\
\hline Unemployed & 210 & $(67.3)$ & 1.0 & $(0.33-3.1)$ & 0.977 \\
\hline Others & 3 & $(0.96)$ & 5.0 & $(0.7 I-35 . I)$ & 0.104 \\
\hline Residence & & & & & 0.001 \\
\hline Urban & 154 & $(49.3)$ & 1.0 & & \\
\hline Rural & 158 & $(50.6)$ & 3.7 & $(2.3-6.2)$ & \\
\hline Opium user & & & & & $<0.001$ \\
\hline No & 134 & $(43.0)$ & 1.0 & & \\
\hline Yes & 178 & $(57.0)$ & 23.0 & $(12.5-42.3)$ & \\
\hline
\end{tabular}

clinic in the Aseer region, Saudi Arabia (61.6\%). ${ }^{[15]}$ A possible reason for the high rates of cigarette smoking in our study could be due to the fact that respiratory infections are the most common reasons among patients who attended the clinic during the winter. Smoking has been found to increase risk of respiratory infection by several bacterial pathogens. ${ }^{[16]}$

In our study, the prevalence of cigarette smoking was higher among males (88.5\%) compared to females (11.5\%). This is consistent with a finding that has been reported by a previous study among adult patients attending an outpatient clinic in India. ${ }^{[14,17]}$ Low prevalence of smoking among females in this study can be linked to social and cultural reasons in the region.

We found an inverse association between smoking status and the level of education. This finding is in line with a survey conducted in India. ${ }^{[18]}$ It is likely that there is an association between the level of education and the level of health literacy. Therefore, an increase in health literacy can result in an increase in knowledge and awareness among people regarding hazards of smoking. ${ }^{[19]}$

The cigarette smoking prevalence was higher among families where parents or other family members or friends were smokers. This finding was supported with findings reported by a previous study in Saudi Arabia among clinic attendees. ${ }^{[20]}$ A possible explanation for this is a social learning theory that people begin to smoke if there are family members or friends who do so. It is believed that they acquire a positive attitude, belief, and behavior for smoking through a social learning model of smoking initiation. ${ }^{[21]}$

In this study, the prevalence of cigarette smoking was higher among rural residents compared to urban residents, which is in accordance with results of other studies. ${ }^{[1,22]}$ The reason for this could be due to lack of awareness among rural residents. Our study showed that literacy rates in rural areas are lower than in urban areas.

Opium use showed an association with smoking cigarette in this study, which is consistent with the results on the association between illicit drug use and cigarette smoking. ${ }^{[23]}$ It is hypothesized that tobacco is a gateway drug to illicit drugs. ${ }^{[24]}$ The increase number of cigarette smoking could be a marker for serious patterns of illicit drug use. ${ }^{[25]}$

This study has some limitations. First, our participants were from a single outpatient clinic that was located in Andkhoy, Afghanistan. Second, the patients were selected on a convenience basis. This could result in the potential for selection bias. Third, this study was conducted on a nonprobability technique, and therefore cannot be generalized beyond the study population. Finally, a cross-sectional study design was used to analyze the association between smoking and its associated factors.

This study, however, provided useful data concerning smoking and its associated factors among adult patients attending an outpatient clinic in Afghanistan. 


\section{CONCLUSION}

The prevalence of smoking among adult patients attending an outpatient clinic in Afghanistan was high. The identified associated factors with smoking were male gender, a family history of smoking or friend history of smoking, level of education, rural residency, and opium consumption. Our findings highlight the need for the effective smoking cessation interventions among the Andkhoy population.

\section{Acknowledgement}

Our study project was subsidized by the Terumo Foundation for Life Sciences and Arts. The authors are grateful to Ms. Terri Stevens for proof reading of the manuscript.

\section{Financial support and sponsorship}

Nil.

\section{Conflicts of interest}

There are no conflicts of interest.

\section{REFERENCES}

1. World Health Organization. Global Health Risks: mortality and burden of disease attributable to selected major risks. Bull World Health Organ 2009;87:646.

2. World Health Organization. WHO Report on the Global Tobacco Epidemic, 2013: Enforcing Bans on Tobacco Advertising, Promotion and Sponsorship. Geneva, Switzerland: World Health Organization; 2013. p. 106. Available at: https://apps.who.int/iris/bitstream/ handle/10665/85380/9789241505871_eng.pdf?sequence $=1$.

3. Saleheen D, Zhao W, Rasheed A. Epidemiology and public health policy of tobacco use and cardiovascular disorders in low- and middle-income countries. Arterioscler Thromb Vasc Biol 2014;34:1811-9.

4. John U, Hill A, Rumpf HJ, Hapke U, Meyer C. Alcohol high risk drinking, abuse and dependence among tobacco smoking medical care patients and the general population. Drug Alcohol Depend 2003;69:189-95.

5. Kouimtsidis C, Reynolds M, Hunt M, Lind J, Beckett J, Drummond C, et al. Substance use in the general hospital. Addict Behav 2003;28:48399.

6. Cottler LB, Ajinkya S, Goldberger BA, Ghani MA, Martin DM, Hu H, et al. Prevalence of drug and alcohol use in urban Afghanistan: epidemiological data from the Afghanistan national urban drug use study (ANUDUS). Lancet Glob Health 2014;2:e592-600.

7. Delavari AR, Alikhani S, Alaedini F. A National Profile of NonCommunicable Disease Risk Factors in the I.R. of Iran. Tehran, Iran: Center for Disease Control, Ministry of Health \& Medical Education; 2005.

8. Hamrah MS, Hamrah MH, Ishii H, Suzuki S, Hamrah MH, Hamrah AE, et al. Association between Helicobacter pylori Infection and cardiovascular risk factors among patients in the northern part of Afghanistan : a cross-sectional study in Andkhoy City. Asian Pac J Cancer Prev 2018;19:1035-9.
9. Lim HK, Ghazali SM, Kee CC, Lim KK, Chan YY, Teh HC, et al. Epidemiology of smoking among Malaysian adult males: prevalence and associated factors. BMC Public Health 2013;13:8. Available at: http://www.biomedcentral.com/1471-2458/13/8.

10. Nasrollahzadeh D, Kamangar F, Aghcheli K, Sotoudeh M, Islami F, Abnet CC, et al. Opium, tobacco, and alcohol use in relation to oesophageal squamous cell carcinoma in a high-risk area of Iran. $\mathrm{Br} \mathrm{J}$ Cancer 2008;98:1857-63.

11. American Psychiatric Association. Diagnostic and Statistical Manual of Mental Disorders. 4th rev. ed. Washington, DC: American Psychiatric Association; 2000. Available at: https://books.google. ro/books/about/Diagnostic_and_Statistical_Manual_of_Men. html?id=qRj7lwEACAAj\&redir_esc $=y$.

12. Musaiger AO. Overweight and obesity in Eastern Mediterranean Region: prevalence and possible causes. J Obes 2011; article ID 407237.

13. James PA, Oparil S, Carter BL, Cushman WC, Dennison-Himmelfarb C, Handler J, et al. 2014 evidence-based guideline for the management of high blood pressure in adults: report from the panel members appointed to the Eighth Joint National Committee (JNC 8). JAMA 2014;311:507-20.

14. Mony P, D'Souza G, Sreedaran P, Rekha D, Srinivasan K. Clinicoepidemiological profile of tobacco users attending a tobacco cessation clinic in a teaching hospital in Bangalore city. Lung India 2012;29:137-42.

15. Alsamghan AS, Bharti RK, Alhussain MA, Chaudhary S, Dealan KA, Karkman MJ, et al. Smoking pattern and determinants among adults attending anti-smoking clinic in Aseer Region, Saudi Arabia. Int J Med Res Health Sci 2017;6:101-6.

16. Bagaitkar J, Demuth DR, Scott DA. Tobacco use increases susceptibility to bacterial infection. Tob Induc Dis 2008;4:12.

17. K Rao P, Bant DD, Community IJ, Public M, Jan H. A study on the pattern of tobacco use and its implications on the health of patients, attending Karnataka Institute of Medical Sciences, Hubballi. Int J Community Med Public Health 2018;5:331-335.

18. Sorensen G, Gupta PC, Pednekar MS. Social disparities in tobacco use in Mumbai, India: the roles of occupation, education, and gender. Am J Public Health 2005;95:1003-8.

19. Shuja M, Sarrafzadegan N, Roohafza HR, Sadeghi M, Ghafari M, Mohammadian $\mathrm{M}$, et al. Factors associated with cigarette smoking in central parts of Iran. Asian Pac J Cancer Prev 2017;18:647-53.

20. Siddiqui S, Ogbeide DO, Al Khalifa I. Smoking in a Saudi community: prevalence, influencing factors, and risk perception. Fam Med 2001;33:367-70.

21. Gilman SE, Rende R, Boergers J, Abrams DB, Buka SL, Clark MA, et al. Parental smoking and adolescent smoking initiation: an intergenerational perspective on tobacco control. Pediatrics 2009;123:e274-81.

22. Cheah YK, Naidu BM. Exploring factors influencing smoking behaviour in Malaysia. Asian Pac J Cancer Prev 2012;13:1125-30.

23. Khan MM, Aklimunnessa K, Kabir MA, Kabir M, Mori M. Tobacco consumption and its association with ilicit drug use among men in Bangladesh. Addiction 2006;101:1178-86.

24. Odukoya OO, Dada MR, Olubodun T, Igwilo UA, Ayo-Yusuf OA. Risk perception and correlates of tobacco use among young people outside of formal school settings in Lagos State, Nigeria. Asian Pacific J Cancer Prev 2016;17:2833-9.

25. Balley S.L. Adolescents' multisubstance use patterns: the role of heavy Alcohol and cigarette use. Am J Public Health 1992;82:1120-4. 